Б. Фаусту. Краткая история Бразилии. Пер. с порт. Л.С. Окуневой, О.В.Окуневой; предисл. Б.Н. Комиссарова; послеслов. Л.С.Окуневой - М.: Издательство «Весь Мир», 2013.

Boris Fausto. Kratkaia istoriia Brazilii. Per. s port. L.S.Okunevoi, O.V.Okunevoi; predisl.B.N.Komissarova; posleslov. L.S.Okunevoi - Moskva: Izdatel'stvo "Ves' Mir", 2013.

Boris Fausto. História concisa do Brasil. Tradução do português para o russo por L.S.Okuneva, O.V.Okuneva; prefácio por B.N.Komissarov; postfácio por L.S.Okuneva - Moscou: Editora "Ves Mir", 2013.

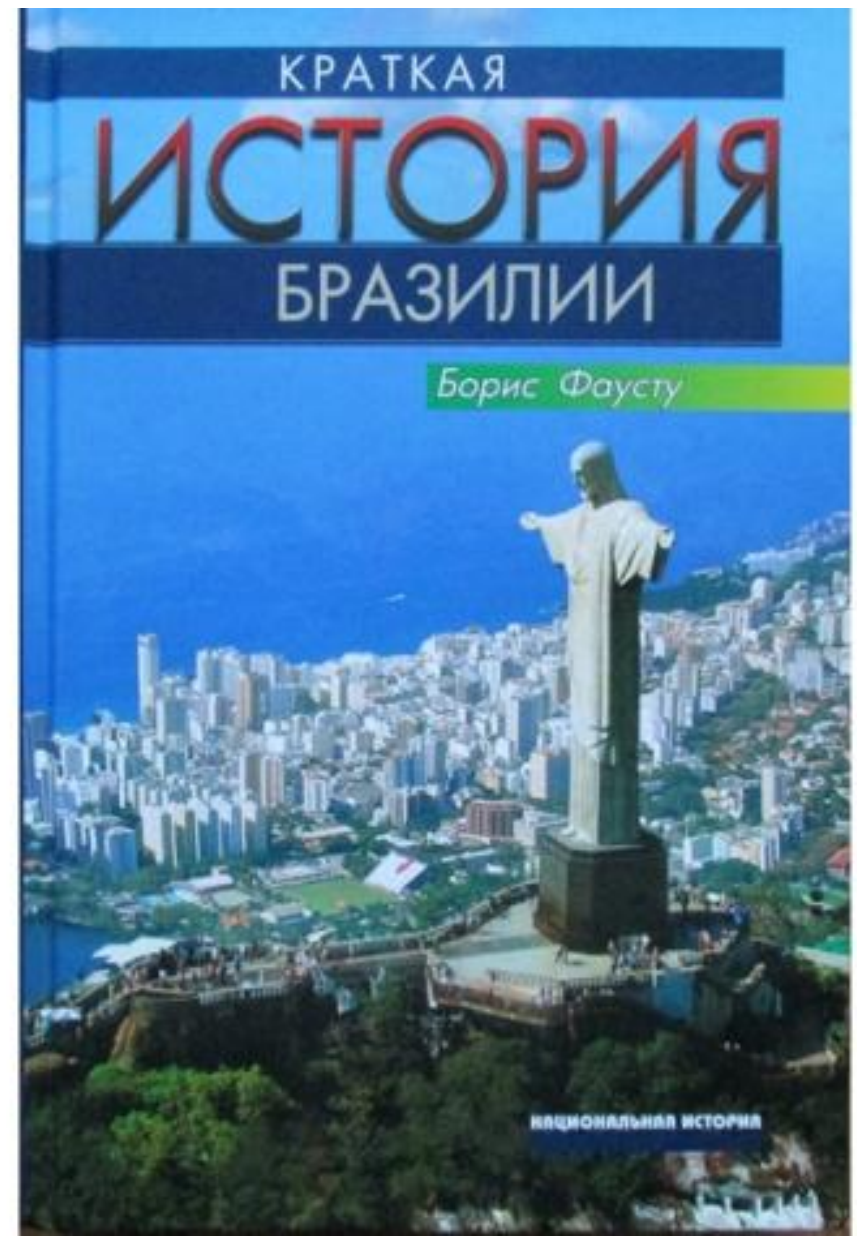

Dr. Andrey Tókarev*

\title{
A história brasileira entra no espaço cultural russo
}

A cooperação cultural e científica russo-brasileira verificou um grande avanço. No marco da série "História Nacional", a editora moscovita "Ves Mir" publicou a versão russa da obra "História concisa do Brasil", do renomado historiador brasileiro Boris Fausto. Muitos pesquisadores russos

\footnotetext{
${ }^{*}$ Chefe do Departamento dos paises da África do Sul, Instituto dos Estudos Africanos da Academia de Ciências da Rússia. Endereço eletrônico: stp79@yandex.ru
} 
de história do Brasil e da América Latina já conheciam a produção acadêmica de Boris Fausto. Hoje, um dos seus mais notórios livros estará disponível não só para especialistas, mas também para o amplo público russo. Com isso, espera-se que a história do Brasil passe a fazer parte do espaço cultural da Rússia.

A tradução foi realizada por uma família moscovita de brasilianistas, precisamente pela Profa. Dra. Liudmila Okuneva e sua filha, Dra. Olga Okuneva.

Liudmila Okuneva é Doutora titular em História, professora titular da Universidade Estatal das Relações Internacionais (MGIMO) junto ao Ministério das Relações Exteriores da Federação Russa, pesquisadora sênior do Instituto de América Latina (ILA) da Academia de Ciências da Rússia. É também especialista em história contemporânea do Brasil, autora de muitas publicações, dentre elas a monografia "Brasil: as particularidades do projeto democrático. Grandes temas da história política contemporânea do gigante latino-americano (década de 60-2006)”, publicada pela Editora MGIMO em 2008.

Olga Okuneva é Doutora em História pela Universidade Estatal Lomonossov de Moscou e pela Universidade Paris-Sorbonne, pesquisadora do Instituto de História Universal da Academia de Ciências da Rússia. Trabalha a problemática das origens da história colonial do Brasil, sobretudo da presença francesa no país no século XVI e no início do século XVII.

Vale destacar que a edição russa não se limita apenas a um trabalho de tradução da obra de Boris Fausto. Ela se inicia com um prefácio elaborado por Boris Komissarov - renomado pesquisador russo das origens das relações russo-brasileiras e da história do Brasil do início do século XIX -, e conclui-se com um amplo postfácio de Liudmila Okuneva, no qual, além das reflexões sobre a importância da obra do renomado historiador, está presente um breve esboço acerca do caminho histórico do país a partir do momento em que termina o livro original (o ano de 1994, marco da chegada de Fernando Henrique Cardoso ao poder) até os nossos dias.

Outra parte muito significativa da presente edição são os comentários das tradutoras, essenciais para o leitor russo compreender melhor a realidade brasileira, os acontecimentos da vida política e outros fenômenos puramente brasileiros. Além disso, eles contribuem para que o leitor russo, sobretudo o que não conhece o Brasil, desperte o interesse pela cultura e historia do país, mergulhando profundamente no âmbito da magnífica nação brasileira.

A edição russa está também acompanhada por uma lista bibliográfica, compilada pela professora Liudmila Okuneva, que inclui a produção historiográfica russa sobre a história do Brasil. Provavelmente o leitor brasileiro da presente resenha se surpreenda ao saber que desde a década de 60 várias obras russas sobre a história socioeconômica e política do Brasil, assim como a sua vida cultural, têm sido publicadas na Rússia. 
É indispensável mencionar o excelente trabalho das tradutoras. Como frequentemente ocorre no processo de tradução, a linguagem original acaba sendo dificultada ou distorcida. No entanto, no caso da presente tradução, conseguiu-se facilitá-la, tornando-a atraente e fascinante para o público russo e ao mesmo tempo mantendo o sentido da versão original da obra de Boris Fausto.

A edição russa tem ainda mais importância por apresentar-se como um marco na retomada de toda uma tradição em traduzir obras brasileiras na Rússia. Nesse sentido, vale mencionar que em 1949 foi traduzido na URSS o livro de Caio Prado Junior, "A história econômica do Brasil” e, em 1976, o livro de Nelson Werneck Sodré - “Brasil: radiografia de um modelo". Mas no que se refere às traduções dos livros de historiadores brasileiros, os dois últimos livros foram editados há mais de meio século! Trata-se das obras "História do Brasil", de Rocha Pombo, e "Brasil. Século XX”, de Rui Facó - ambas editadas em 1962.

Sem dúvida alguma, a edição russa do livro de Boris Fausto, publicada no ano comemorativo do $185^{\circ}$ aniversário do estabelecimento das relações diplomáticas Brasil-Rússia, aproximará ainda mais os nossos povos, contribuindo para uma melhor compreensão mútua. Não é por acaso que o lançamento ocorreu no dia 20 de novembro de 2013, data da visita oficial à Rússia do Ministro das Relações Exteriores do Brasil, Sr. Luiz Alberto Figueiredo.

Para concluir, vale mencionar que o livro de Boris Fausto - agora traduzido do português para o russo - já ocupa o digno lugar na historiografia russa sobre o Brasil, atraindo novas gerações de jovens pesquisadores e orientando-as no estudo das peculiaridades históricas desse grandioso país, parceiro estratégico da Federação Russa no continente latino-americano. 